\title{
The Presence of María de Velasco in Pinar's Juego trobado, in the Carajicomedia, and in La novela del licenciado Vidriera by Cervantes
}

\author{
Roger Boase \\ Queen Mary, University of London \\ R.Boase@,qmul.ac.uk \\ https://orcid.org/oooo-oooI-68oI-8598 \\ Received 02/OI/2O2I; accepted 30/OI/2O2I \\ DOI: https://doi.org/IO.7203/MCLM.8.16552
}

\begin{abstract}
Research on the court ladies who participated in Pinar's Juego trobado, a card game in verse completed in I 496 , led to the discovery that María de Velasco, wife of Juan Velázquez de Cuéllar, and adoptive-mother of Ignatius Loyola, subsequently appears in several literary texts, the first of which is the Carajicomedia, where she is metamorphosed into an old prostitute skilled in the arts of seduction. Surprisingly, I have detected her presence in La novela del licenciado Vidriera, one of Cervantes' Novelas ejemplares: each of the names of the main character, given or adopted during the course of his life, is linked in some way with this lady; and, furthermore, there are other correspondences, above all the symbolism of the quince. This begs the question whether the tale was intended to convey a coded message, and if so, one wonders what kind of message. This discovery also seems to add some credence to the theory that in Don Quixote Cervantes wished to parody the life of Ignatius Loyola as well as the heroes of chivalric romance.
\end{abstract}

\section{KEYWORDS}

Cervantes; Pinar; María de Velasco; Carajicomedia; Crónica burlesca; La Lena; Batallas y quinquagenas; Don Quixote; Vidriera; Ignatius Loyola; Juan Velázquez de Cuéllar; Germana de Foix, King Fernando; cantharides; symbolism of quince; peacocks; parrots; melancholia

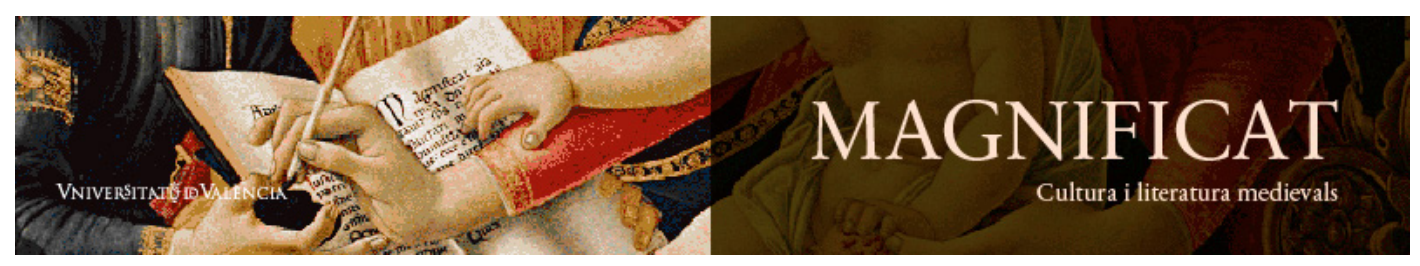

Magnificat Cultura i Literatura Medievals 8, 202I, 33-55. http://ojs.uv.es/index.php/MCLM

ISSN $2386-8295$ 
RESUMEN

Las investigaciones sobre las damas de la corte que participaron en el Juego trobado de Pinar, un juego de cartas en verso acabado en I 496, me han llevado a descubrir que María de Velasco, mujer de Juan Velázquez de Cuéllar, y madre adoptiva de Ignacio de Loyola, aparece posteriormente en varios textos literarios, el primero de los cuales es la Carajicomedia, donde ella se transmuta en una vieja puta experta en las artes de seducción. Más sorprendente, he detectado su presencia en La novela del licenciado Vidriera, una de las Novelas ejemplares de Cervantes: cada uno de los nombres del protagonista, dado o adoptado durante el curso de su vida, tiene conexión en cierto modo con esta dama; y además, hay otras correspondencias, sobre todo el simbolismo del membrillo. Habría que pensar que la intención del autor fue comunicar un mensaje en clave, y si esto fuera el caso, me pregunto qué tipo de mensaje encierra. Este descubrimiento también puede dar más credibilidad a la teoría de que en Don Quïote Cervantes deseaba parodiar la vida de Ignacio de Loyola tanto como los heroes de los romances de caballería.

PALABRAS CLAVE

Cervantes; Pinar; María de Velasco; Carajïcomedia; Crónica burlesca; La Lena; Batallas y quinquagenas; Don Quijote; Vidriera; Ignacio de Loyola; Juan Velázquez de Cuéllar; Germana de Foix; el rey Fernando; cantárida; simbolismo del membrillo; pavos reales; papagayos; melancolía.

Roger Boase. 202I. 'The Presence of María de Velasco in Pinar's Juego trobado, in the Carajicomedia, and in La novela del licenciado Vidriera by Cervantes', Magnificat Cultura i Literatura Medievals, 8: 33-55, DOI: https://doi.org/IO.7203/MCLM.8.I6552 


\section{ə*⿻丷木}

$\mathrm{M}_{\mathrm{a}}$

aría de Velasco y Guevara (c. I467-I54I) is best known as the adoptive-mother and distant aunt of St Ignatius Loyola (I $49^{\mathrm{I}-\mathrm{I} 55^{6}}$ ), the founder of the Jesuit order, who entered her large household as a pageboy in ${ }_{5} \mathrm{O} 5$ or 1506 when her husband Juan Velázquez de Cuéllar was granted tenure of the fortress of Arévalo (Diago Hernando I980: I68), a position that his father Licenciado Gutierre Velázquez de Cuéllar had once held when the latter was responsible for the affairs of Isabel de

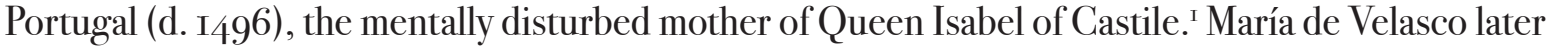
acquired some notoriety as the court lady who administered a love-potion to King Fernando that may have seriously damaged his health and led to his painful death in ${ }_{5}{ }^{1} 6$. This, I believe, would explain her presence in the anonymous and highly obscene Carajicomedia (st. 20, Varo I98I: I62), where, as Diego Fajardo's guide to the prostitutes of Spain, she is the counterpart to the damsel personifying Providence in Juan de Mena’s Laberinto de Fortuna (Domínguez 2007-2008).

She is identified as the person alluded to in stanza I7 of Gerónimo Pinar's Juego trobado (Boase 2OI7), a poetic game completed in the summer of I 496 . She also appears in Francés de Zúñiga’s Crónica burlesca del Emperador Carlos $V$, fully completed for the entertainment of the court by ${ }{ }^{529},{ }^{2}$ and in La Lena, o El celoso, a play by Alfonso de Velázquez de Velasco, published in Milan in $\mathrm{I} 6 \mathrm{O} 2$. I have since then made the astonishing discovery that there appear to be hidden references to her in Miguel de Cervantes' La novela del licenciado Vidriera, which is one of his Novelas ejemplares. ${ }^{3}$

Carajicomedia, a parody of Laberinto, is ostensibly about Diego Fajardo's pursuit of a remedy for his impotence. Its satire exposes the hypocrisy of the royal court and the corruption of church dignitaries, indirectly mocking the king's authority and caricaturing the court ladies as common prostitutes. ${ }^{4}$ Maria de Velasco, who must have conveyed the impression of being always pregnant because she had a dozen children, six sons and six daughters, not including her adopted son St Ignatius (Fernández Martín I980: 35-39), is satirised as an old prostitute, nicknamed La Buiza (which is a village near Valladolid), who -like the old procuress Celestina- is an expert in repairing hymens and in rejuvenating old men. She appears in stanza 20 and in its prose commentary (Varo

I. In I506, Juan Velázquez’s position as Chief Accountant of Castile was also confirmed. Formerly, he had been in charge of Prince Juan's education and financial accounts from March I 495 until the latter's sudden death on 6 October I 497. He later looked after the affairs of Prince Miguel, the son of Queen Isabel's eldest daughter, who died in Granada at the age of two on 20 July I500. Fidel Fita (I890: 495) was of the opinion that Juan Velázquez and his wife adopted St Ignatius as a young child in I 496 , but he offers no substantiating evidence, nor is this likely, because it was said that when Ignatius moved to Arévalo he could already read and write. It was also said that he was present at the court of King Fernando, not the court of the Catholic Monarchs, which suggests a date later than 26 November I5O4 when Queen Isabel died (Fernández Marín I980: 22-23, 30).

2. Pascual de Gayangos published the first printed edition in I855 (Curiosidades bibliogáficas, BAE 36 ).

3. I owe this discovery to Trevor Dadson. At a book-launching seminar that I gave at Queen Mary, University of London, on I6 February 2OI7, my discussion of the symbolism of the quince had prompted him to suggest that I should take a look at this short and curious tale, which I did with surprising results. I am deeply indebted to Stephen Boyd, University of Cork, who patiently analysed several versions of this paper and drew my attention to some articles that I was not aware of.

4. See Boase 20I7, chapter 6. Domínguez (2007-2008) identifies the old bawd María de Vellasco [sic] as the wife of Juan Velázquez de Cuéllar, but he does not mention any other court ladies satirised as prostitutes. In fact, María de Velasco is one of the few women in the Carajicomeda whose identity is not disguised. 
I981: I62) as a dried-up old woman, over one hundred years of age, who pretends that she is in the throes of childbirth and who restores Fajardo's penis to its former potency:

Quien esta vieja sea, el autor, por vergonçoso, no lo declara; pero es de saber qu' ella se llamó en tempos antigos [sic] María de Vellasco. Ya por discurso de sus maldades pereció aquel nombre. Solamente agora se conosce y llama, hablando con reverencia, la Buyça, que cierto es en la villa de Valladolid tan temeroso de oír como el de Celestina. [...] Su vida es tan ynominiosa que no la quise aquí poner, por no inficionar más el tratado. ¡Baste!, que juro a Dios que creo ab inicio no nació mayor puta, ni alcahueta, ni hechicera, sin más tachas descubiertas, con las quales oy en día permanece en la ribera d'Esgueva mesonera, y ella es la tablilla. [...] Inter natus [sic] mulierum non surrexit major puta vieja que María la Buyça (Varo I981: I62-63).5

María de Velasco is also a target for the more subtle humour of the court jester Francés de Zúñiga who, in his Crónica burlesca del Emperador Carlos V (Zúñiga I98г: II5), gives us a pathetic portrait of her seated on a rock beside the flooding waters of the river Tagus, complaining about her children and her financial problems. This would have been in 525 when she had to cross the Tagus en route to Portugal to join the court of Catherine of Habsburg. She is later reincarnated as a procuress, also named La Buiza, in La Lena, o El celoso, a play published half a century after her death that was influenced by La Celestina (Velázquez de Velasco I6o2; Gutiérrez 1992). After running a brothel in Naples for thirty years, La Buiza, like her namesake in the Carajicomeda, ends her days as an innkeeper on the banks of the Esgueva, the river that flows through Valladolid.

In order to understand how María de Velasco achieved this mythical literary status, it should be

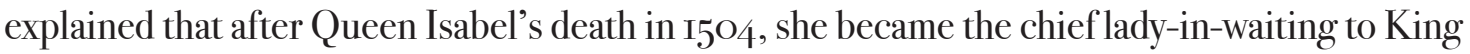
Fernando's second wife, Germana de Foix (I488-I8 Oct I538), daughter of Jean de Foix, Compte d'Étampes, and Marie d'Orléans, sister of Louis XII of France. Before María became estranged from Germana, she encouraged the queen's taste for lavish banquets, and her friendship with the queen was very close, in fact, in the opinion of Lorenzo Galíndez de Carvajal (I851: $3^{8} 5$; cf. Fita I89o: 516), she was "amiga más de lo que era onesto". Similarly, Fray Prudencio Sandoval informs us that María de Velasco could not be parted from the queen for a single day. ${ }^{6}$

King Fernando's chief aim in marrying Germana de Foix was to produce a male heir to inherit the throne of Aragon and Naples. The marriage was consummated on I8 March I5O6 at Dueñas. In I5o9, three years later, Germana gave birth to a son in Valladolid, but the baby only lived for a few hours and died on 3 May. María de Velasco's main task during these years seems to have been to endeavour to restore the king's virility, which is why she was selected to play a central role in the Carajicomedia, a work completed shortly after the king's death. ${ }^{7}$ In March I513, in Carrioncillo, near Medina del

5. 'Out of shame, the author does not make it known who the old woman is. But you should know that in the old days she was called María de Vellasco [sic]. On account of her iniquities that name perished. Now, speaking with reverence, she goes by, and is known as, La Buiza, a name which is certainly as fearful to hear in the town of Valladolid as that of Celestina. [...] Her life is so ignominious that I did not wish to set it down here in writing lest the treatise be further defiled. Enough!, for I swear to God, I believe that since the world began no greater prostitute, nor go-between, nor witch, with so many exposed blemishes, has ever been born, faults that she still retains to this day as an innkeeper on the banks of the Esgueva, and she herself is the signboard. [...] Among those born of women never did there arise a greater old whore than María La Buiza'. These last words are clearly a travesty of the words of Jesus: "Among them that are born of women there hath not arisen a greater than John the Baptist” (Matt. II: II).

6. 'Fué muy hermosa, generosa y virtuosa, y muy querida de la Reina Doña Isabel: con la reina doña Germana, tuvo tanta amistad, que no podía estar un día sin ella; y doña María no se ocupava en otra cosa, sino en servirla y banquetearla costosíssamente' (Sandoval i625: I, 77).

7. María de Velasco would have been a widow in her fifties after the death of her husband on I2 August I5I7. After November ${ }^{5} 5^{\mathrm{I}} 6$ her husband was in open revolt against the authority of Charles of Habsburg and Cardinal Cisneros, 
Campo, María de Velasco, on the advice of Germana and with the help of Isabel Fabra, prepared a stew made of bull's testicles and certain herbs to cure his impotence (Galíndez de Carvajal I878: $565)$. This potion seems to have permanently damaged the king's health because he remained an invalid from this period onwards until his death at the age of sixty-four in an inn in the village of Madrigalejo, near Cáceres in Extremadura, on 23 January I5I6, on his way from Guadalupe to Seville, and some people even said that María de Velasco had given him poison (Santa Cruz 195I: 2, 280-8I). These rumours are repeated in Argensola's continuation of Zurita's Anales ${ }^{8}$ and in Fray Prudencio Sandoval's history of the reign of the Emperor Charles V. ${ }^{9}$ When the king died, he was suffering from a pain in the heart and hydropsy, or edema, and although the swelling was reduced by diarrhoea, his health only deteriorated. Judging by the symptoms displayed, it is very likely that his death was caused by cantharides, or cantharidin (cantharis vesicatoria), made from the ground dust of the blister beetle (lytta vesicatoria), or Spanish fly (cantárida), a metallic green beetle found on the leaves of lime-trees and ash. This substance, which has been known since the time of Hippocrates, was widely used as an aphrodisiac in Spain and Italy at this time. ${ }^{\text {IO }}$

By г5I María de Velasco was such an influential figure at the royal court that Lucio Marineo Sículo wrote to her about his plans to write a book on the famous women of Spain, but it is doubtful that this book was ever completed (Lynn I937: 229). At that time she was at the height of her prosperity and her palace at Arévalo must have rivalled that of many monarchs because she had acquired a vast amount of Queen Isabel's possessions when these were auctioned in 1505 several months after her death (Fernández Martín I980: 53-92), and in the years I5O6-I5I5 she received the royal court on several occasions as it passed through Arévalo as she had likewise done during Queen Isabel's lifetime, ${ }^{\text {II }}$ but her fortunes changed dramatically after King Fernando's death in I5I6.

From November I5I6 until March I5I7 Arévalo was in a state of military alert because her husband was in open rebellion against the Crown after he refused to relinquish the revenues and manorial rights of Arévalo, Madrigal and Olmedo to Queen Germana to replace the revenue of 30,000 ducats that she had formerly received from Naples, and it was then that there was a rupture in relations between María de Velasco and Queen Germana. When Juan Velázquez died exhausted in Madrid on I2 August I5I\%, his widow was left with massive debts so that she was obliged to sell her properties in Valladolid and Arévalo (Diago Hernando 2009: I85). In I525, when Catherine of Habsburg (I5O7-I578), the youngest daughter of Philip the Fair and Juana La Loca, married João III of Portugal, María de Velasco was appointed as Catherine’s chieflady-in-waiting. After fostering her

which meant that she and her husband were out of favour and there was no need to conceal her identity. This is a point also made by Domínguez (2015: I67).

8. "adoleció de una grave enfermedad [...] ocasión de un feo potaje que la Reina le hizo dar para más habilitarle, que pudiese tener hijos. Esta enfermedad se fue agravando cada día, confirmándose en hidropesía con muchos desmayos, y mal de corazón: de donde creyeron algunos que le fueron dadas yerbas" (Argensola 2OI3: 2, 52-53, cf. $5^{2}$ nI27).

9. "Y a la verdad su enfermedad fué hidropesía con mal de corazón, aunque algunos quisieron decir que le habían dado yerbas, porque se le cayó parte de una quijada; pero no se pudo saber por cierto más de que muchos creyeron que aquel potaje que la reina le dió para hacerle potente, le postró la virtud natural” (Sandoval I955-56: I, 63). These rumours are discussed in more detail in Frank Domínguez’s book on the Carajicomedia (20I5: I6I-66).

IO. Cantharidin is highly toxic and was sometimes used as a poison or as an abortifacient. Andrés Laguna (I999: $5^{8}$ i; bk VI, chap i), in his translation of Dioscorides, recounts how some men had died after taking an overdose of it as an aphrodisiac. I am not the first to suggest that the stew of bull's testicles served up to the king in I5 ${ }^{\mathrm{I} 3}$ must have contained an excessive dose of cantharidin. This hypothesis has been discussed by medical experts and is accepted as highly probable in a recent history of Aragon (Fernández Clemente \& Marco Simón 20o8: r9).

II. The royal court visited Arévalo in July I506, August I5O7, and in April, July and August in I5I5. For further details, see Rumeu de Armas 1974 . 
younger children among relatives, she travelled to Portugal to enter Catherine’s service (Fernández de Oviedo 1983-2002: I, 448), and she was to remain there for the rest of her life.

Let us now consider the stanza in Pinar's Juego trobado (ID6637; IICG-875, I4CG-948; st. I7), ${ }^{\text {I2 }}$ addressed to María de Velasco:

Vos tomad un membrillar,
porque sois dama discreta,
pues la carne más perfeta
se haze d'aquel lugar.
Y ell ave será un pavón
haziendo siempre la rueda,
cantando con lindo son
la canción de "Bive leda".
Y el refrán, que "Don Ximeno
por su mal vee el ageno".

María de Velasco's character is evoked by the four elements that are allotted to her: an orchard of quinces, a peacock, the song "Bive leda [si podrás]", and the proverb "Don Ximeno por su mal vee el ageno" (Correas 2000: 238; Bizzarri 1995: 85, no. 20I; Nuñez 200I: I, no. 23O4, fol. 37r). It would seem highly appropriate, bearing in mind what we know concerning María de Velasco’s love of banquets that she be given a peacock and an orchard of quinces.

The peacock not only conveys this lady's vain and narcissistic character, and her ability to flirt and display her beauty and finery, but it also, I believe, alludes to her love of fine food, because as we know from Platina's famous cook-book, De honesta voluptate et valetudine, this bird was often an eye-catching centrepiece in banquets, standing upright on iron rods and sometimes covered with gold leaf to make it even more magnificent. ${ }^{13}$

Quinces are associated with marriage, fertility and sex. Quince paste, or quince cheese, dulce de membrillo, marmelada (Portuguese), marmelo (Galician), codonyat (Catalan), cotognata (Italian), a very thick deep red jelly, made with either sugar or honey, has long been prized, like partridge and peacock, as an aphrodisiac, and in ancient Greece this fruit, named chrysolmela, or "golden apple", was sacred to Aphrodite. At the end of banquets organised by princes and aristocrats in sixteenth-century Europe, it was customary to pass round the table quince pastes, known as quiddiny or cotoniack, pressed into decorative seals. The word "marmalade", from marmelo, Portuguese for quince, which is now used for any jam made from citrus fruit, entered the English language from Portuguese in the late fifteenth century, and London prostitutes in the seventeenth century were often called "marmalade madams" because they would ply customers with their quince marmalade (Wilson 2000: 23, I 47-I5I; Wilson 2000: 32; Hemery \& Simblet 20I4: I35-37). This is the real reason why, according to Andrea Alciato, Solon recommended the quince, or Cydonian apple (cotonea), as a gift for newlyweds, not merely because it makes the breath sweet (López I6I5: Emblema 202; first edn Lyons I549). It was perhaps also as a wedding gift that quince-jelly, carne de membrillo, and a pea-hen, pava, were among several items sent to the poet Juan Álvarez Gato by Alonso Carrillo's lady-friend, mentioned in the poem "El presente que me distes" (SV $2-58 \mathrm{c}, \mathrm{ID}$ 2745).

I2. All ID numbers and sigla for texts cited in this paper are from Brian Dutton (I99O-I99I). Note that, except in the list of contents of the Cancionero general(Valencia I5II), Pinar is identified merely by his patronymic.

I3. This work was completed in Naples by I $_{4} 65$ and printed in many editions from I 470 onwards. Platina informs us that the meat of this bird is in fact only moderately nourishing and increases melancholy (I998: 242-45, 274-77). 
Quince was not only an aphrodisiac, associated with fecundity and conjugal love, but it was also a euphemism for the female sexual organ. Covarrubias explains this by means of a false etymological link ${ }^{14}$ between membrillo and membrum (Covarrubias I6II: 545):

La etimología de membrillo traen algunos del diminutivo de la palabra membrum, por çierta semejança que tienen los más dellos con el miembro genital y femíneo.

Patricia Parker, who wrote an article on quince imagery with reference to the name of Peter Quince in Shakespeare's A Midsummer Night's Dream, cites the following entry from Minsheu's Guide unto the Tongues (I6I $)$ that associates the quince with both the male and female genitalia:

Quince, a kind of fruit, from French Coing [...] Italian Mela cotogna, pomo cotogno [...] Latin Malum cotoneum, cydonium, Malum canum [...] Malum Lanatum [cottony and 'wooly' apple], because of its wooly or downy covering. Greek melon kudonion, from Cydonia (a city in Crete), and lasiomelon ('wooly apple'), from lasios or hirsutus ('hairy' or 'rough with down'), and melon, or Latin pomum ('apple'). Portuguese Marmelo, Spanish Membrillo, from membrum, [...] because of a certain similarity with the first pubic hairs of men and women. ${ }^{15}$

This whole line of reasoning is, however, insufficient to explain why a quince-grove was María de Velasco's special emblem. The answer lies concealed in Fernández de Oviedo’s Batallasy quinquagenas, a work completed in I555, but not published until I88o. In his portrait of María de Velasco's husband, Juan de Velázquez de Cuéllar, the author informs us that he wore a piece of jewellery made of beryl (Fernández de Oviedo I983-2002: I, 452):

Johan Velázquez yo no le vi moço; pero vile fresco e hermoso, ombre de buen jesto, e ya gordo e de auctoridad; e mostrava aver sido quando mançebo de linda dispusiçión. E dezían que avía seydo gentil justador e muy galán cortesano. E trahía sobre el yelmo una mançana de veril, por aprovecharse de veril (por Velasco). Porque, como ya sabéys, en Castilla es cosa muy usada que la invençión se conforme con el nombre de la dama por quien se invinçiona. E aquí quadra la mançana con María, y el veril con Velasco. Y ese veril es vidro, que tanbién es a propósito. Y en la misma mançana debuxada una muerte. E por las dependençias del yelmo o baúl, çiertas calaveras humanas, significando la muerte, que es la más çierta cosa que los ombres tienen en este mundo, y una letra que dezía: "Aquí puedes ver, mortal, / quién tú eres siendo tal”. ${ }^{16}$

Fernández de Oviedo then explains, citing from the encyclopaedia of Bartholomaeus Anglicus, ${ }^{17}$ that, according to Dioscorides, beryl, like glass, burns the hand of the person carrying it by

I4. It is generally agreed by Corominas and others that membrillo derives from the Latin melimelum, 'sweet apple', and the Greek melimelon.

I5. John Minsheu, Doctor in Lingua (London, I6I7), cited in Parker 2003: 39. Many other passages concerning quinces by Cervantes and his contemporaries are cited in Gómez Canseco 2015.

I6. 'I never saw Juan Velázquez when he was a lad; but I saw him when he was a fresh and handsome man, with a good face, and already stout and commanding; and he had evidently been fine-looking in his youth. And they say that he had been a noble jouster and a very gallant courtier. And he wore on his helmet an apple made of beryl, to avail himself of [the word] veril (for Velasco); because, as you already know, in Castile it is commonly the practice for the jousting invención to allude to the name of the lady for whom it is composed. And here the apple corresponds to María, and beryl to Velasco. And this beryl is glass (vidrio), which is also appropriate. And on this same apple a corpse was drawn. And on the trappings of the helmet there were some skeletons, signifying death, which is the most certain thing that men have in this world, and an inscription that said: "Here you may see, mortal one, / what you are, mortal as you are" (Fernández de Oviedo I983-2004: I, 452; my translation).

I7. In citing De propietatibus rerum, bk I6, chap 2I, Fernández de Oviedo was almost certainly using the Spanish 
magnifying the rays of the sun, and it is thus a stone imputed with the property of increasing conjugal love. The same information is found in the Liber lapidum seu gemmis by Marbod (c.IO35II23), Bishop of Rennes: "This stone comes to us from the Indies. It is said that it promotes conjugal love and that it strengthens those who wear it. It burns, they say, the hand of those who hide it in the palm" (Jones 20I3: 99).

It is almost certain, however, that Fernández de Oviedo made a pardonable mistake: the piece of jewellery worn by Juan Velázquez, made of green or yellow beryl, was intended to represent a quince and not an apple, because one would expect the apple, manzana, to evoke the name Ana, not María, as it does for the recipient of an apple-tree in stanza 39 of Pinar's Juego trobado, where this tree helps the reader, or listener, to identify Ana de Mendoza y Enríquez, daughter of Diego Hurtado de Mendoza, first Duke of El Infantado (Boase 2OI7: 37I). What's more, I suggest that if the word for beryl in Castilian is spelt with a v, veril, this surely indicates that María de Velasco was viril, virile, an adjective often applied to Queen Isabel as a term of approbation (Boase I978: II2-I3).

By assigning an orchard of quinces to María de Velasco, it would also seem that Pinar is predicting that her husband will be offered the post of Comendador de La Membrilla del Tocón in the Order of Santiago, a fortress in La Mancha, near Ciudad Real, although it was not until I5O7 that this office was conferred on him by King Fernando, when his son Gutierre Velázquez (c.I484-I5I7) was assured the right to succeed to it. The father apparently renounced his right to this office between I5II and I5I5 (Porras Arboledas 1997: 336; Diago Hernando 20o9: I7o n36).

Finally, I come to consider La novela del licenciado Vidriera, a tale that many critics have found bizarre, disturbing and "deeply pessimistic" (Clamurro 20I5: II7). It may seem unlikely that there could be any connection between this short tale by Cervantes and Pinar's Juego trobado, or to imagine that there could be any allusion in this work to María de Velasco and the events leading up to King Fernando's death. However, both works are concerned with the problem of identity and contain names that the reader, or listener, is invited to decipher. This is perhaps what Cervantes had in mind when, in his prologue addressed to his patron the Count of Lemos, he suggested that there was some mystery concealed in his tales. ${ }^{18}$

The tale about the licenciado Vidriera, or Tomás Rodaja, is primarily concerned with its hero's desire to bring honour and fame to his family by creating a name that will survive the grave. Cervantes seems to have set out to prove that an individual's reputation (nombre) does not derive from a high-ranking name, or from inherited property and titles, but from personal achievements. However, the identity and reputation of the main protagonist keeps shifting with each new phase of his life, and what is remarkable is that each seems to be linked in some way to María de Velasco. ${ }^{19}$ The symbolism of the quince and certain parallels between Don Quijote and Tomás Rodaja, on the one hand, and María de Velasco's adopted son St Ignatius Loyola, on the other, would seem to add credence to this theory. Furthermore, another María was, in a sense, Tomás Rodaja's adopted mother: he always carried with him on his travels a copy of the Hours of the Virgin, ${ }^{20}$ and the place that seems to have impressed him the most during his travels in Italy was the Sanctuary of Loreto, an important shrine of Marian pilgrimage, dedicated to "the Divine Mother", where it was believed

translation by Fray Vicente de Burgos (Bartholomaeus Anglicus I494).

I8. Stephen Boyd (2005: 3I-40) suggests that the "misterio escondido" is associated with human identity, the nature of free will, and the inscrutability of Divine Providence.

I9. It should also be noted that the names Rodaja, Vidriera, Rueda, and even the unflattering nickname Señor Redoma are feminine. Molho (I995: 4OI) makes this observation with reference to Rodaja's latent -or not so latenthomosexuality, and his close friendship with the military captain Diego de Valdivia.

20. The only books that he took with him were "unas Horas de Nuestra Señora y un Garcilaso sin comento", in short, literature inspired by devotion to a sublime ideal of femininity. 
that the Holy House of Nazareth, where the Annunciation occurred ("la más alta embajada"), had been literally transported by angels (Molho I995: 400).

Since at least nine editions of the Cancionero general were published in the period I5II-I573 (Perea Rodríguez 2OI4: I56), it would not have been difficult for Cervantes to procure a copy of this anthology where he could have read Pinar's Juego trobado. At the same time, it is equally possible that he was familiar with rumours of the role that María de Velasco may have played in causing -or at least contributing to- the decline in King Fernando's health, and he may well have known by hearsay about Juan de Velázquez's use of the quince emblem.

In the works of Cervantes, there is nothing random about the author's choice of names. In Don Quixote, there is a similar concern with the pursuit of fame and the indeterminate nature of human identity. Cervantes creates doubts about the name of his fictional character, an impecunious gentleman (hidalgo) of obscure origins, and draws attention to the importance of names by denying his authorial omniscience: we are told at the outset that some authors (fictitious) suggest that the name of this gentleman was either Quijada or Quesada, but more likely Quejana; much later, in the last chapter of Part II, the reader is informed that his real name is Alonso Quijano. By renaming himself Don Quijote de La Mancha, Quijano, like Rodaja, seeks to attain a nobler status in the world and to achieve eternal renown and fame (cobrase eterno nombre y fama, Part I, I), although, in his case, his aim is to become the living example of a knight-errant of chivalric romance, imitating not Christ, but Amadís de Gaula. In this quest, he spends four days thinking what name he should give to his miserable nag (rocín), and he opts for Rocinante, a sonorous name befitting its owner's professed status as a knight-errant (rhyming with caballero andante), and one that harks back to its origins ("nombre, a su parecer, alto, sonoro y significativo de lo que había sido cuando fué rocín, antes de lo que ahora era, que era antes y primero de todos los rocines del mundo"), and he transforms the identity of the peasant woman Aldonza Lorenza by christening her Dulcinea del Toboso, a name that to his ears sounds strange and musical and suitable for a princess, indicating at the same time that she was born in Toboso, near Toledo. ${ }^{21}$ It has even been suggested that, in the title-page layout of the I6o5 edition of Don Quixote, the name has been deliberately split in two (Qui-xote) in order to create a play of words: xote, or çote, is synonymous with idiota, or ignorante, while don Qui makes the hidalgo into the son of a nobody, a don Nadie, or hijo de nada, instead of an hijo de algo, a nameless person in search of his identity (Redondo 2011: 23-25).

At the start of La novela del licenciado Vidriera, the central character, then an eleven-year-old boy, has no name. Two nameless noblemen studying at Salamanca, who chance to meet him and who judge from his dress that he is of humble origins, ask him where he comes from and where he is going. He replies that he has forgotten his place of birth, which - as one of the noblemen at once perceives- is patently a lie..$^{22}$ Indeed, we later learn that what makes him excel as a student is a sound memory: “Tenía tan felice memoria, que era cosa de espanto" (Cervantes 20I3: 267). When,

2I. There is a close parallel to this passage in Huarte de San Juan's Examen de ingenios (chap. 8), a work with which Cervantes was evidently very familiar: Huarte considered that the sound of words was no less important than their meaning, and that there should be a natural correspondence between words and things; and he recounts that a Spanish knight, who amused himself by writing books of chivalry, spent many days thinking of a suitable name for a ferocious giant until, while playing cards with a friend, he heard someone calling for drinks "Hola, muchacho, tra qui tantos a esta mesa" (trae aquí tantos), and immediately he knew that Traquitantos would be a suitable name for a giant (Iriarte i933: 52O-2I; Huarte I989: 42O-2I). Later, in chapter I3, Huarte illustrates the importance of names by another anecdote: Alfonso IX of Castile had two daughters, Urraca and Blanca, and although Urraca was the eldest and more beautiful, the French ambassadors chose Blanca as a more suitable bride for their royal master because her name would be better received in France (Huarte I989: 56 I).

22. One may compare this wilful forgetting to that of the narrator of Don Quixote in framing his novel: "En un lugar de La Mancha, de cuyo nombre no quiero acordarme". 
in a later phase of his existence, he is addressed as "licenciado Vidriera", or simply "Vidriera", or Glass-Case, because he suffers from the delusion that he is made of glass, he tells the courtiers that what actors need most is hard work and a good memory, and that a person's pedigree is the least important of qualifications. The boy explains to the two noblemen that no one will know the name of the place of his birth, nor that of his parents, until he has made a name for himself, which he seeks to do initially by pursuing an academic career. He feels that it is his primary duty to earn a name for himself in order to bring honour to his parents and his country. This is why, as a boy, he is on his way to the city of Salamanca to look for a master whom he may serve in exchange for instruction. He has a good understanding and, as we have mentioned, a sound memory, but he is not endowed with a strong will, the third faculty of the soul: one has the impression that throughout his life he is a passive victim of circumstances and forces outside his control. ${ }^{23}$

The novel is summed up at the end in these paradoxical words: "la vida que avía començado a eternizar por las letras la acabó de eternizar por las armas", expressing the triumph of arms over letters. ${ }^{24}$ Even the process of vitrification, which he imagines that his body has undergone as a consequence of eating a love-potion, could be regarded as an unconscious attempt to attain immortality because glass is a substance that may break but does not decompose; such is his phobia of all physical contact that for two years he imagines that he is literally glass: "Soy vidrio". By linking the verbs comenzar and acabar to the idea of eternity, Cervantes seems to imply that Tomás Rodaja's pursuit of fame has been an illusion. He loved literature, and when he was temporarily insane, he achieved some renown at court for his witty and perceptive remarks. But he was only a second-rate law student, and he did not achieve any distinction as a scholar. Indeed, judging by the largely topographical notes that he makes when travelling in Italy, his literary talents are mediocre. Eventually, after opting to pursue a military career in the company of his friend Captain Valdivia, he died valiantly in Flanders, or so the narrator assures us, without disclosing the circumstances.

During the course of the story, the main protagonist is given three different names that reflect three phases in his life. When he enters the service of the two noblemen, who offer to sponsor his studies, he is known as Tomás Rodaja. The name Tomás suggests that, like the disciple "Doubting Thomas", he has a sceptical and inquiring mind. Rodaja is clearly not his real surname, but a derogatory form of the word Rueda, suggesting that he is incomplete, or just a small cog in the Wheel of Fortune. ${ }^{25}$ Given that rodaja derives from the verb rodar , 'to wander', this word also conveys the notion of restlessness: an outsider of no fixed address who roams the world. Since raja may mean a slice of fruit, it has even been suggested that the word R[od]aja expresses his sense of alienation and rootlessness, preserving a fragment of the symbolic quince from which he originated; in short, he is a species of membrillo: "un miembro tajado o recortado" (Garcés 1995: 23I). In a later phase of the tale, he acquires the name Vidriera, from the nature of the madness resulting from eating a quince. Then, when he has recovered from his madness and frequents the royal court, he tells people that he is neither "Rodaja", nor "licenciado Vidriera", but "licenciado Rueda". This is not a name given to him by others, but a name that he has consciously chosen for himself (García Lorca 1965: I6I). He is now a fully rounded person: the small or incomplete circle is complete, but he ceases to attract public attention, having lost the reputation for wit (ingenio) that

23. One finds a similar rootlessness in other Cervantes characters. For example, Diego Cortado, later named Cortadillo, in the Novela de Rinconete y Cortadillo, who seeks to prove his skill as a cardsharp and a cutpurse in the company of his friend Rincón, is reluctant to disclose his name and disclaims any connection with his place of birth because his father has disowned him.

24. Cervantes 20I3: 30I; 'The life that he had begun by "eternalising" through scholarship, he ended by "eternalising" by means of arms'.

25. Cf. Sancho Panza’s words: “¿Habrá quien eche un clavo en la rodaja de la Fortuna?” (Don Quixote II: r9). 
he had possessed when he was mad. The plebeian Rodaja has been replaced by Rueda, a name with aristocratic associations, reminding us of Rueda de Velasco, in León, the place whence one branch of the Velasco family is said to have originated: "y siempre han llamado y llaman de Velasco los que han tenido y tienen aora la Rueda de Velasco" (Fernández de Velasco, Origen de la Yllustrísima Casa de Velasco, fol. $4^{\mathrm{r}}$ ). This change of name seems to have been chiefly motivated by Rodaja's ambition to rise up the social ladder: María de Velasco belonged to the family of Fernández de Velasco, who were Counts of Haro and Dukes of Frías, and claimed a hereditary right to the office of Constable of Castile. ${ }^{26}$

Readers of Pinar's Juego trobado may also recall that rueda is a key word in the stanza allotted to María de Velasco: the idiom "hacer la rueda", which means to court a woman, derives from the courtship ritual of the male peacock when it opens up its splendid tail (rueda), a ritual so well described in the poetry of Nicolás de Guevara, addressed, I believe, to María de Guevara, María de Velasco's mother. ${ }^{27}$ In the third stanza of "El seso turvio pensando" (IICG-2IO), one of his finest poems, Guevara writes:

Y las aves, dulces, ledas, cantarán sus alboradas, $\mathrm{y}$, a vista de sus amadas, harán los pavos las ruedas. Pues a mí, triste, no queda sino suerte de, sin verte, ver la rueda de mi muerte..$^{28}$

Guevara condenses the eight stanzas of this poem into one short esparsa (IICG-2I5), in which he again mentions peacocks and blames himself for bringing about his own misfortune:

Las aves andan volando, cantando canciones ledas, las verdes hojas temblando, las aguas dulces sonando, los pavos hazen las ruedas. Yo, sin ventura amador, contemplando mi tristura, deshago, por mi dolor, la gentil rueda d'amor, que hize por mi ventura. ${ }^{29}$

26. Bernandino Fernández de Velasco, María de Velasco’s uncle, was awarded the title of Duke of Frías in I492. 27. The poet Guevara must have been well acquainted with Juan Velázquez’s father Licenciado Gutierre Velázquez de Cuéllar, because, since the period when Isabel was an unmarried princess (I464-68), he had been a visitor to Arévalo, where the Velázquez family looked after the affairs of the Queen Mother.

28. 'And the sweet and merry birds / will sing their dawn-songs, / and within the sight of their loved ones, / the peacocks will raise their tails. / But to me there remains, sadly, / only the good fortune, / if I don't see you, of seeing / the wheel of my death'.

29. 'The birds go flying by, / singing their merry songs, / the green leaves are trembling, / the sweet waters babbling, / the peacocks are raising their tails. / I, the unfortunate lover, / contemplating my sadness, / undo through my sorrow / the graceful wheel of love / that I made by my good fortune'. 
If the name Rueda alludes to the peacock's rueda as well as to Rueda de Velasco, then Cervantes found no difficulty in deciphering the Juego trobado. But it also raises many questions that one cannot begin to resolve without examining a puzzling incident that occurs in the middle of the narrative. While Tomás Rodaja is studying at Salamanca, he meets "una dama de todo rumbo y manejo" (Cervantes 20I3: 275, 'a lady of worldly experience and feminine wiles'). We are told that the students of Salamanca used to flock to visit this lady like birds drawn to a decoy. Tomás wishes to meet her after hearing that she too has travelled widely in Italy and Flanders. She falls in love with him and offers him her fortune, implying that she wishes to marry him. To judge from her conduct, she was a courtesan rather than a prostitute. Tomás refuses to be distracted from his studies and fails to reciprocate her love -partly, it seems, because he does not wish to compromise his freedom. She feels rebuffed and seeks the advice of a Moorish woman, who concocts a love-potion with a Toledan quince (which is María de Velasco's emblem). But, instead of producing the desired effect, the potion triggers the delusion that he is made of glass.

According to Cervantes, or his narrator, the purpose of the love-potion was to break the young man's will, but he then remarks (2OI3: 276):

las que dan estas bebidas o comidas amatorias se llaman veneficios, porque no es otra cosa lo que hacen, sino dar veneno a quien la toma, como lo tiene mostrado la experiencia en muchas y diversas ocasiones..$^{30}$

It would seem that Cervantes may have had King Fernando's death in mind when he made this comment, drawing attention to the harmfulness of certain aphrodisiacs, such as cantharidin, by means of the neologism veneficios instead of maleficios, both the very antitheses of beneficios.

It is noteworthy that this is not the only place in this tale where quinces or quince-trees are mentioned. Membrilla, a district in La Mancha, is included in a list of Spanish wines, competing with Italian and Greek ones, offered by an innkeeper in Genoa to the Spanish soldiers who carouse and make merry in order to "forget the storms of the past". Most of these wines have feminine-sounding names, thus associating femininity with intoxication, and one of them, Esquivias, calls to mind the wife of Cervantes, Catalina de Palacios y Salazar, a native of Esquivias near Toledo, from whom the author had been formally separated since ${ }_{5} 5^{8} 7$ by means of a generous power of attorney (Eisenberg I999: I43-49). This name is itself appropriate because it evokes the idea of elusiveness or disdain (esquivez), a traditional characteristic of the ladies to whom poets would address their amatory verses.

Glass is a subtle substance offering an escape from corruptible matter and the world of the flesh, conveying the idea of human fragility and alienation, and it is a good metaphor for the naked truth, or candour, or clarity, of Vidriera's perceptive observations. However, it will also be recalled that María de Velasco's husband wore an image of a quince made of beryl, veril (or berilo), a semiprecious stone that was regarded as a type of glass, and that the words vidrio and vidriera begin, like the name Velasco, with the letter V. On one occasion, a young muleteer addresses Tomás as "señor redoma" (Cervantes 20I3: 286), which could mean either a glass flask such as was used by pharmacists and alchemists for mixing drugs, or "a crafty fellow"..$^{3 \mathrm{~T}}$

What makes this tale so difficult to interpret correctly is that one has to differentiate between Cervantes and his narrator: readers are easily duped by an unreliable narrator into underestimating

30. '... those who give these love-potions and foods are called 'poisoners', because all they do is poison the person who takes them, as experience has shown on many and various occasions'.

3г. "De aquí llamamos redomado al hombre cauteloso y astuto" (Covarrubias i6II: fol. I56 6 ). 
the worth of Tomás Rodaja and admiring the "sagacity" of the more memorable and insane "licenciado Vidriera", whose jokes take up more than half the space accorded to the whole tale, but only two years of his life. It is significant that it is as "el licenciado Vidriera", the name accorded to him by the populace, that he is remembered by posterity, hence the title of the tale, although this "transparent" name is paradoxically a mask that conceals his vulnerability and hides his "true self". Readers have thus generally failed to appreciate that Tomás Rodaja (later renamed Tomás Rueda) is the real exemplary character and protagonist of the story: "the most significant (and necessarily discrediting) thing one must concede about the narrator is that he values Vidriera's vacuous words more than he esteems the exemplary life of the talented and appealing Tomás Rueda" (Shipley 2002: II4; cf Shipley 2OOI, 2005). In other words, like the public at large, the narrator values Tomás more highly as a madman than as a scholar or a soldier. The mad Vidriera is neither a professional court jester nor a born fool; he is not free to exercise any judgement and he shows no empathy or curiosity; he only knows how to survive by winning the approval and applause of the populace and by satisfying the whims of his noble patron, and he achieves all this by his skill in coining witty uncharitable aphorisms that reflect received opinion and magnify popular prejudices, appealing to his auditors' baser instincts and sometimes targeting the most vulnerable members of the community, including New Christians, or descendants of Jews and Muslims. On the whole, the rich and powerful are spared the barbs of his wit, although he does slip in some anti-clerical jests that are entirely consistent with the traditional madman's role as vox populi. One could thus say that in this section of his tale Cervantes is not only satirising the satirist (Price 1992: 6I) but also, in some cases, condemning genuine social vices without incurring any risk of censorship.

One should add that one reason for the respect accorded to Vidriera by the populace, which Shipley fails to mention, is that the symptoms of his madness, such as his aversion to sunlight, his irrational fears, his talkativeness, his freedom from social constraints, and even the delusion that he is made of glass, would have been immediately recognised as indicative of melancholia, a fashionable disease of the soul associated with divination, perspicacity and clairvoyance (Speak r990: 857). In fact, one finds many similar contemporary psychiatric cases, notably a case, recounted by Juan Huarte de San Juan, of a pageboy in the service of a grandee who acquired great wit and intelligence as a consequence of his mental illness and was accordingly treated with enormous respect (Iriarte I933: 506-O7; Schleiner I99I: 372; Huarte I989: 308-o9). The chief difference is that Vidriera, whose natural tendency to melancholy is rendered acute by the poisonous aphrodisiac, derives no pleasure from his changed mental condition and is glad to be cured. ${ }^{32}$ Still more striking are the parallels between the symptoms of Vidriera's mental illness and those of a patient of Alfonso Ponce de Santa Cruz, Philip II's personal physician, whose work Cervantes could have read in manuscript while the court was residing in Valladolid in the period I6oI-I6o6 (Redondo I98I: 38). The case history was published by Santa Cruz's son Antonio, also a doctor, at least half a century afterwards in I622. The patient not only believed that he had been transformed into a glass vase but, like Vidriera, he slept on a bed of straw and avoided all physical contact for fear of being broken (Santa Cruz 2005; Johnson 1983: I7).

Another curious link between María de Velasco and the Cervantes tale is that the court jester Francés de Zúñiga, in his Crónica burlesca del Emperador Carlos V, parodying a speech made by Jesus to the women of Jerusalem as he is being led to the crucifixion, jokingly reports that the following epitaph was inscribed on María de Velasco’s tomb: ‘ $¡$ Mulieres de España, nolite flere

32. Cervantes was influenced by his reading of Huarte's Examen de ingenios (Baeza I575), which had already been printed in several editions, although he seems to have disagreed with his determinism (Soufas I990: I-36; Iriarte I933). For the general symptoms of melancholia, see Babb i95. 
super me sed super filios meos!' (Zúñiga: r981: II5: 'O women of Spain, do not weep over me, but over my children!'). ${ }^{33}$ Her children had been a constant source of anxiety because her husband at his death in $5_{5} \mathrm{I}$ had left debts amounting to I6 million maravedies and she needed money for the dowries of her daughters. ${ }^{34}$ Tomás, during the period of his insanity, parodies this same biblical passage in the first of his witty sayings. Addressing a clothes-dealer in Salamanca, who says that she feels sorry for him, but cannot weep, he responds with an insult: "Filiae Hierusalem, plorate super vos et super filios vestros" (Cervantes 2OI3: 27.9). The woman's husband finds this remark malicious perhaps because it raises suspicions about the legitimacy of her children and hints at the supposed blemish of her converso ancestry (Ibid. 279 n92). Although the coincidence between the inscription on the tomb and Vidriera's words is striking, it is admittedly such a popular passage of scripture that it is doubtful if it can be taken as evidence of a specific debt to the Crónica burlesca.

Two events, both again connected to María de Velasco, may have had some part to play in the genesis of La novela del licenciado Vidriera, which, it is thought, was written when the royal court was in Valladolid in I6o5 or I6o6. The first event, which we have already mentioned, is the publication in I602 of La Lena, o Elceloso by a member of the Velasco family, Alfonso Velázquez de Velasco, who, like Tomás Rodaja, had travelled as a soldier in Italy and Flanders, about a woman of Valladolid whose nickname, La Buiza, enables us to identify her as María de Velasco. This semiautobiographical comedia gives us a picture of the decadent social life in Valladolid a couple of decades before the time when Cervantes was writing. The second event was the birth in Valladolid of an eagerly awaited heir to the Spanish throne on 8 April i6o5, namely Felipe, the eldest son of Felipe III (I578-I62I) and his cousin Margaret of Austria, who succeeded to the throne in I62I when he was barely sixteen years old as Felipe IV of Spain and who also became Felipe III of Portugal. It was once again a time when the question of royal succession had become a matter of serious concern, and the episode of the quince (María de Velasco's fruit) provided Cervantes with a pretext for issuing a warning against the dangers of certain aphrodisiacs at a time when the king was anxious to produce a male heir.

I would argue that the correspondences that I have discussed demonstrate two things: first of all, that one is justified in speaking of María de Velasco's presence in La novela del licenciado Vidriera, which means that the moral truths embedded in this work of fiction may have both a historical basis and a ludic function; and secondly, that Pinar's Juego trobado was still not totally impenetrable to writers such as Cervantes who lived over a century later. However, this tale is not just an elegant witty court entertainment like Pinar's game. The theme of personal identity is explored at a much deeper level, and so we are left with many unanswered questions about the author's motives in creating such a complicated network of correspondences. There are two avenues that I believe are worth examining: one concerning his attitude to his Jewish ancestry; the other concerning his attitude to women.

33. "Conversus autem ad illas Iesus dixit: 'Filiae Ierusalem, nolite flere super me, sed super vos ipsas flete et super filios vestres, quoniam ecce venient dies, in quibus dicent: Beatae steriles et ventres, qui non genuerunt, et ubera, quae non lactiverunt!' But Jesus turning unto them said, "Daughters of Jerusalem, weep not for me, but weep for yourselves, and for your children. For, behold, the days are coming, in which they shall say, Blessed are the barren, and the wombs that never bare, and the paps that never gave suck!' (Luke 23: 28-29).

34. It is incredible that such debts had accumulated when one considers that most of his sons and daughters were in royal service and that in November I5I4 the estates to which his eldest son Gutierre Velázquez had a right to succeed were valued at I 4 million maravedies (Diago Hernando 2009: I74; Fita I890: 504). These debts must have arisen as a consequence of military expenditure and his wife's extravagance in the purchases that she made of precious objects that had formerly belonged to Queen Isabel. Juan Velázquez had been the chief executor of Queen Isabel's will and would have had a detailed inventory of her goods when these were sold at auction. 
Lineage and purity of blood had become an obsession in Spain in the age of Cervantes. María de Velasco's husband Juan Velázquez de Cuéllar belonged to a wealthy family of Jewish ancestry that arose to prominence in the service of Fernando de Antequera and his son Juan II of Aragon (Diago Hernando I99I), a family that by the early sixteenth century had a network of business connections in Spain, France and Flanders. It is also likely that Ignatius Loyola's maternal grandfather Martín García de Licona was a converso (Ingram 2006: 87-80). One therefore wonders whether the sustained reference to María de Velasco in this tale, a lady in whose household Ignatius was raised, also implies that there is a coded message here about the author's own Jewish ancestry, a message that would only have been picked up by certain categories of readers, including certain members of the royal court in Valladolid.

The young man's "apparent" indifference to the seductive lady whom he meets in Salamanca raises the question of Cervantes's attitude to women. It has been remarked that in the works of Cervantes those women who are easily available, or who seek to entrap men, arouse feelings of aversion (Eisenberg 2004). Eisenberg notes that Cervantes did not find happiness in marriage, and he argues that there are few happy marriages in his works; marriage is regarded as a necessary social institution, but it is not perceived as a desirable state; sexual desire is portrayed as destructive; and friendship, so it seems, can only truly exist as a bond between two men. The friendship that exists between Tomás and Captain Diego de Valdivia is certainly a good example of this. ${ }^{35}$ His meeting with the captain, which is described in such precise topographical detail, "al bajar de la cuesta de la Zambra, camino de Antequera", is described by one critic as his "vision on the road to Damascus" and a mutual seduction (Molho I995: 389 ), diverting him from his academic vocation to a life of military adventure. It may be countered, however, that several tales by Cervantes, notably $L a$ gitanilla, El amante liberal, La ilustre fregona, La española inglesa, and La fuerza de la sangre, end with what the narrator intimates was a "happy" marriage; and, with the exception of the La fuerza de la sangre, this is plausible. ${ }^{3}$

But we are still faced with many questions: Can we assume that Tomás, like Cervantes, associates this woman with María de Velasco? If this be the case, did Tomás choose the name Rueda because of its associations with her family, and would discerning readers have linked the name Rueda with her? Did Tomás merely want the prestige that this name would bring? When a gentleman assumes, or receives, a lady's name as his own, this is normally evidence that he is in love with her, which does not seem to be true of Tomás. One thinks of the poets Jamil ibn Ma'mar, or Jamil Buthayna, and Qays ibn al-Mulawwah, or Majnûn Layla, whose poetry and the legends that they inspired had an enduring impact on Arab love-poetry and, indirectly, on the rise of the European love-lyric. Both poets were from the Bani 'Udhra, a seventh-century Bedouin tribe renowned as martyrs of love. Qays Majnûn was so intoxicated by his passion for Layla bint Sa'd al-Amiriya that he went mad and lost his own personal identity, which is how he came to be known as Majnûn Layla, which means "crazy for the love of Layla". Sufis made this pre-Islamic tale a parable of man's quest for God, and it inspired a long narrative mystical poem by the thirteenth-century Persian poet Nizami, a work that was widely imitated (Boase 1977: 65, 94).

35. Diego de Valdivia is the only other person in this tale who is assigned a name, and in choosing this name Cervantes may have wished to pay tribute to Diego de Valdivia, Alcalde de la Real Audiencia in Seville, who in $5_{587}$, when the author was short of money, obtained a post for him as a commissary charged with the task of requisitioning wheat, barley and oil in preparation for the Armada (Fitzmaurice-Kelly r9I3: 7I). The name Valdivia is also associated with the missionary work of the Jesuits. One thinks notably of Father Luis de Valdivia, who studied the languages of the indigenous people of Chile and on his return to Madrid in I6o9 proposed the idea of a defensive war with some respect for indigenous rights, a policy that was in fact rejected.

36 . This is a point made to me by Stephen Boyd in a private communication. 
In fifteenth-century Spain there is the example of Don García de Toledo, Lord of La Horcajada, near Ávila, second son of García Álvarez de Toledo, the first Duke of Alba, who was known as "Mayor Don García" because he was so much in love with his wife, or future wife, Doña Mayor de Toledo, daughter of Gutierre de Solís, Count of Coria, and Doña Francisca de Toledo, daughter of Fernando Álvarez de Toledo, Lord of Oropesa (d. I462) (López de Haro I622, I: 22I-27). He is one of the four judges selected as an expert in matters of the heart in a poem by the knight Juan Barba (ID 2993, MNI9-8I) in order to pass judgement on his young squire Guevara for having written his Sepultura de amor. ${ }^{37}$ She, I believe, was the lady who inspired the anonymous canción "Nunca fue pena mayor", by far the most popular courtly song in Spain during the fifteenth and early sixteenth century (Boase 20I7: 5 ${ }^{\mathrm{IO}-33}$ ).

Tomás Rodaja's situation is not analogous to that of these renowned lovers because his insanity is caused by a love-potion, not by love itself, and in fact, as I have said, there is no indication whatsoever that he is in love with the courtesan who gave him the potion. Since the quince is not only a traditional wedding gift but is, according to some, the type of fruit that Eve offered Adam, this episode loosely calls to mind the Genesis story. Stephen Boyd (2005: 34), however, makes the following comment: "Since he has resisted the woman who gave it [the potion] to him, the incident obviously cannot be read as a direct reworking of the story of Eve's temptation of Adam, but rather as a displaced image of the damage done to him by his own unbalanced desire to know". In other words, his bout of madness could be viewed as a punishment for his idle curiosity and self-centred pursuit of knowledge (Redondo I981: 37), or a product of his innate melancholic temperament combined with his devotion to the Virgin Mary..$^{3}$

If one accepts the theory that, at one level, the first part of Don Quixote, completed by i604, could be regarded as a subversive burlesque parody of the life of Ignatius Loyola (Ortés 20O2, Wehr 2OII, Davidson 2OI2), then it would be hardly surprising to find that Cervantes was acquainted with many details of the life of the saint's adoptive-mother María de Velasco. Although in recent years many Cervantes experts have rejected this critical approach, less than five years after the publication of the work, students at the University of Salamanca recognised the resemblance between the knight of La Mancha and St Ignatius because it formed the basis of a comic masque, entitled El triunfo de don Quijote, performed in January r6ı in honour of the saint (Buezo I990).

St Ignatius could have been the prototype for Don Quijote because he was also an hidalgo obsessed by the heroes of chivalric romance (especially Amadís), who later, after battle injuries compelled him to abandon the idea of a military career, exchanged the role of a knight errant for that of a pilgrim, playing that role with the same reckless courage that he had displayed in battle. St Ignatius discovered his spiritual vocation in the imitation of the life of Jesus Christ and the lives of the saints, and in developing a method of contemplation in his Spiritual Exercises that would enable a novitiate to relive, or to re-enact, scenes from the life of Christ by means of the transformative lens of a vivid imagination (Wehr 20II:I6I, I66). Just as for Don Quijote the two worlds of chivalric

37. Pedro Cátedra (ı989: 340) calculated that Guevara’s Sepultura must have been written before I464 because, misled by Don García’s nickname, he confused him with his father, the Duke of Alba. Barba describes Don García as follows: “un fijo del Conde de Alba de Tormes, / Mayor Don García, que así lo nombró”. Since Enrique IV of Castile conferred the title of duke on Don García’s father on I2 November I469, this proves that Barba’s response to Guevara’s Sepultura was composed before that date, probably shortly after November I 468 when, at Ocaña, Princess Isabel rejected King Afonso of Portugal's offer of marriage.

38. Alban K. Forcione (I982: 275) writes: “The symptoms of his mental disorder [...] symbolize the isolation, egocentricity, and misanthropy that result from a misguided intellectualism and a pursuit of knowledge for improper reasons". Sampayo Rodríguez (I986: 73-74) makes the same point. It would seem that he is a committed celibate, like Don Quijote, "el más casto enamorado [...] que de muchos años a esta parte se vió" (Cervantes i978: I, 58). 
romance and everyday reality are constantly blurred, so for St Ignatius every moment of the present is imbued with sacred history. It is also highly significant that the word quijote, which refers to a piece of armour worn to protect the thigh, was the precise part of the body where St Ignatius was seriously wounded, so that his leg bones had to be reset by a surgeon and he was at first obliged to bandage his wound with a quijote made of cloth. In other words, this word refers to the key event that led him to the discovery of his religious vocation (Davidson 2005: I42). The word mancha, which not only refers to a barren region of Extremadura characterized by poverty and rusticity, also means "blemish", "stigma", or "disgrace", and would have seemed amusingly incongruous to contemporary readers because it is antithetical to the concept of a knight; it implies that Don Quijote, like St Ignatius - and for that matter Cervantes- bears the "stain" of New Christian ancestry (Redondo 2OII: 23).

Furthermore, there are obvious parallels between certain episodes in Don Quixote and events that are recounted by St Ignatius in his laconic Autobiografia, dictated between I553 and I555 and widely circulated in manuscript, and repeated by the Jesuit historian Pedro de Ribadeneyra in his verbose Vida de Ignacio Loyola, written in Latin in I569 and first published in Spanish in $5^{8} 33^{39}$ both works with which Cervantes as a student of the Jesuits would probably have been familiar. For example, in chapter 3, prior to his being dubbed a knight by the innkeeper, Don Quijote keeps vigil over his armour at night and appeals to Dulcinea to grant him her favour and protection. Similarly, St Ignatius, in chapter 2 of his Autobiografia, at the end of March I522, one year after his legs had been shattered by a cannonball at the siege of Pamplona, recounts how he was inspired by his readings of chivalric romance to dedicate himself to the service of God and to the service of Mary -a lady whom, as he says in an earlier paragraph, has a rank higher than that of any countess or duchess- by keeping vigil all night before the altar of Our Lady of Montserrat, where he hung up his sword and dagger (Loyola ig63: 97):

Y fuese su camino de Monserrate, pensando, como siempre solía, en las hazañas que había de hacer por amor de Dios. Y como tenía todo el entendimiento lleno de aquellas cosas, Amadís de Gaula y de semejantes libros, veníanle algunas cosas al pensamiento semejantes a aquellas; y así se determinó de velar sus armas toda una noche, sin sentarse ni acostarse, mas a ratos en pie y a ratos de rodillas, delante el altar de nuestra Señora de Monserrate, adonde tenía determinado dejar sus vestidos y vestirse las armas de Cristo. ${ }^{\circ}$

I could cite other parallels between St Ignatius and Don Quijote, but to do so would be beyond the scope of this paper. What is more to the point is that there are also parallels between Tomás Rodaja and the founder of the Society of Jesus: both studied at the University of Salamanca as young men; 4i $^{\mathrm{I}}$ both frequented the royal court and were disillusioned by it (Ladero Quesada 1993); both were smart dressers, dreaming of military glory and personal honour; and both were guided by their devotion to the Virgin Mary. St Ignatius, in the very opening sentence of his Autobiografía, admits that his choice of a military career was dictated by "a vain and overpowering desire to gain renown". When Tomás refuses to be conscripted under the regimental standard because this is

39. Vida del P. Ignacio de Loyola, fundador de la Religión de la Compañía de Iesus. It was republished with revisions in $\mathrm{I}_{584}$, I586, I594, I595, and 1605 , the year in which the first part of Don Quixote was published.

40. 'And he took the road to Montserrat, thinking, as he was always wont to do, about the deeds that he had to do for the love of God. And as his whole mind was filled with such things, with Amadis of Gaul and similar books, similar thoughts to those came to him; and so he decided to keep a vigil over his arms for a whole night, without sitting or lying down, but sometimes standing and sometimes kneeling, before the altar of Our Lady of Montserrat, where he resolved to leave his clothes and attire himself in the arms of Christ'.

4I. Ignatius Loyola studied at Alcalá de Henares, Salamanca and Paris. 
against his conscience, Captain Valdivia remarks that he has the conscientiousness of a person in holy orders: "Conciencia tan escrupulosa [...] más es de religioso que de soldado" (Cervantes 2OI3: 269); and it is said that when he renounces his black student's attire and dons a gaudy colourful uniform, he looks like a parrot and a soldier of Christ. ${ }^{42}$ There is possibly the suggestion here that the sombre student's gown is more dignified and more suited to his misanthropic nature. The word escrupulosa is highly significant because scrupulosity and pusillanimity were regarded as the typical characteristics of a person with a melancholy disposition, plagued by anxieties and doubts (Speak I990: 863). It will be noted that when he is insane, he does not allow any jokes to be made at the expense of the clergy; and it is through the healing skills of a Hieronymite friar that he is cured. It would seem, however, that as in the case of so many of the characters in the works of Cervantes, the protagonist's chief concern is to preserve his freedom rather than to commit himself to a religious cause. It was, above all, the love of adventure and the opportunity to travel and to see the cultural sights of Italy that tempted him to join the troops.

The centrality of the theme of freedom in the works of Cervantes is of course not unrelated to the author's experience of five years as a captive in Algiers (I475-I480) (Sánchez I997: 23). As I have pointed out during the course of this article, there are several parallels between the character of Rodaja and that of the author. In particular, it has been suggested that, in this tale, Cervantes expresses his sense of grievance that he had failed to achieve the wealth or public recognition that he deserved and that his undoubted intellectual genius had not been fully appreciated, which was one reason why, like Rodaja, he decided to pursue a military career (Green I970: I85-92). Cervantes also, at the age of twenty-two, visited Rome, where he entered the service of Cardinal Acquaviva, and then later travelled to Naples, where he enlisted as a soldier.

To conclude, there are, as we have seen, hidden signs or mysteries in the works of Cervantes that attentive readers are invited to decipher, in which life and literature are closely intertwined. One of these mysteries is the presence of María de Velasco as a femme fatale or archetypal courtesan in La novela del licenciado Vidriera, which tallies with the theory that her adopted son St Ignatius Loyola was, in some sense, present in Don Quixote, and thus seems to add credence to the theory that in Don Quixote Cervantes wished to parody the life of St Ignatius Loyola as well as that of the heroes of chivalric romance. Both works would seem to be about the ambition of an individual with a melancholic temperament to rise above his origins in the pursuit of fame and to shape his own destiny and identity in a world seemingly ruled by the Wheel of Fortune (rueda de la fortuna). I cannot claim to have fully solved the puzzle, but I am sure that experts on Cervantes may take this research further. ${ }^{43}$

42. "Habíase vestido Tomás de papagayo, renunciando los hábitos de estudiante, y púsose a lo de Dios es Cristo, como se suele decir" (Cervantes 2OI3: 270). Note there is a connection between the words papagayo and membrillo: both are synonyms for the vagina. In La historia de la donzella Teodor, a late thirteenth-century work of Arab origin, the slave-girl Teodor is questioned about coitus by the second of the three wise men, and she recommends that the papagayo be touched prior to sexual union in order to ensure that the woman's orgasm coincides with that of her male partner. One assumes that in the fifteenth century papagayo still retained this meaning, especially if we consider these lines in Francisco Delicado's Retrato de la Loçana Andaluza (Venice, I528): “quien veza a los papagayos a hablar, me vezará a mí a ganar” (Delicado I975: xlii, 306) ('anyone who trains parrots to speak will teach me to earn money’). Since Lozana earns her living by working in Rome as a prostitute, and even alludes at one point to "la donzella Teodor", these words obviously have a double-entendre.

43. A further point worth adding as a postscript is the existence of parallels between Tomás Rodaja and the anonymous author of the Carajicomeda: although, as regards morality, they had little in common, they were both students of law at the University of Salamanca; they both had a preference for literature; they both could be regarded as misogynists; and they both frequented the court, yet were of humble origin. The anonymous author mentions the Italian jurists Bartolus de Saxoferrato and Baldus de Ubaldis in his gloss of stanza 7 I and parodies their style. He also has a taste 


\section{Works Cited}

Argensola, Bartolomé Leonardo. 20I3. Anales de Aragón [continuation of Zurita’s Anales], vol. 2, ed. by Javier Ordovás Esteban (Zaragoza: Institución Fernando el Católico)

Babb, Lawrence. I95I. The Elizabethan Malady: A Study of Melancholia in English Literature from 1570 to 1642 (East Lancing: Michigan State College Press)

Bartolomaeus Anglicus. I494. Libro de las propiedades de todas las cosas [De propietatibus rerum], trans. Fray Vicente de Burgos (Tolosa: Henrique Meyer de Alemania)

Bizzarri, Hugo Oscar (ed.). I995. Ínigo López de Mendoza, Marqués de Santillana, Refranes que dizen las viejas tras el fuego (Kassel: Reichenberger) [Seville: Jacobo Cromberger, I5o8]

Boase, Roger. 1977. The Origin and Meaning of Courtly Love: A Critical Study of European Scholarship (Manchester: Manchester University Press)

Boase, Roger. 1978. The Troubadour Revival: A Study of Social Change and Traditionalism in Late Medieval Spain (London: Routledge \& Kegan Paul)

Boase, Roger. 20I7. Secrets of Pinar's Game: Court Ladies and Courtly Verse in Fifteenth-Century Spain (Leiden: Brill), 2 vols

Boyd, Stephen. 2005. A Companion to Cervantes's Novelas Ejemplares (Woodbridge, Suffolk: Tamesis)

Buezo, Catalina. 1990. 'El triunfo de don Quijote: una máscara estudiantil burlesca de I6Io y otras invenciones', Anales Cervantinos, 28: 87-98 <https://doi.org/IO.3989/ anacervantinos.I990.429>

Bunn, Elaine. 2004. 'Fashioning Identities in El licenciado Vidriera', Cervantes: Bulletin of the Cervantes Society of America, 24: п19-36 <https://users.pfw.edu/jehle/cervante/csa/articso4/ bunn2.pdf>

Cátedra, Pedro (ed.). 1989. La historiografía en verso en la época de los Reyes Católicos: Juan Barba y su Consolatoria de Castilla (Salamanca: Universidad de Salamanca)

Cervantes, Miguel de. 1978. Don Quijote de la Mancha, ed. by Luis Andrés Murillo (Madrid: Castalia) 3 vols

Cervantes, Miguel de. 20I3. Novelas ejemplares, ed. by Jorge García López (Madrid: RAE), pp. 265-3OI

Clamurro, William H. 20I5. Cervantes's 'Novelas Ejemplares'? Reading their Lessons from His Time to Ours (Lanham, MA: Lexington Books)

Correas, Gonzalo. 200o. Vocabulario de refranes y frases proverbiales (1627), ed. by Louis Combet, revised by Robert Jammes and Maïte Mir-Andreu (Madrid: Castalia)

Covarrubias, Sebastián de. I6II. Tesoro de la lengua castellana o española (Madrid: Luis Sanchez) <https://go.uv.es/8zNRirS $>$ 
Davidson, Philip. 2005. Don Quixote de Loyola: Cervantes' Reputed Parody of the Founder of the Society of Jesus, MA dissertation (Victoria, BC, Canada: University of Victoria) $<\underline{\text { http: } / / h d l}$. handle.net/1828/5195>

Davidson, Philip. 20I2. 'Don Quijote de Loyola: sus asociaciones por lectores a lo largo del tiempo', Cuadernos de Aleph, 4: 47-74 <https://go.uv.es/QtfB8hy>

Diago Hernando, Máximo. 199I. 'Los Velázquez de Cuéllar, tenientes de Arévalo, en el horizonte político castellano a fines de la Edad Media', Cuadernos Abulenses, I6: II-40

Diago Hernando, Máximo. 2009. 'El Contador Mayor Juan Velázquez de Cuéllar: ascenso y caída de un influyente cortesano en la Castilla de comienzos del siglo XVI', Cuadernos de Historia de España, 83: 157-85

Domínguez, Frank A. 2007-2008. 'Carajicomedia and Fernando el Católico’s Body: The Identities of Diego Fajardo and María de Velasco', Bulletin of Hispanic Studies, 84: 725-44; 85: 397-416

Domínguez, Frank A. 20I5. 'Carajicomedia': Parody and Satire in Early Modern Spain, with an Edition and Translation of the Text (Woodbridge: Tamesis)

Dutton, Brian. I990-9I. El cancionero del siglo xv, c. 1360-1520, Biblioteca Española del Siglo XV Serie Maior, I (Salamanca: Universidad de Salamanca), 7 vols

Eisenberg, Daniel. 1999. 'El convenio de separación de Cervantes y su mujer Catalina', Anales Cervantinos, 35: I43-49 〈https://doi.org/I0.3989/anacervantinos.I999.008>

Eisenberg, Daniel. 2004. 'La supuesta homosexualidad de Cervantes', in Siglos dorados: homenaje a Augustín Redondo (Madrid: Castalia), i: 399-410

Eisenberg, Daniel. 2008. 'La actidud de Cervantes ante sus antepasados judaicos', in Actas del Coloquio Internacional de la Asociación de Cervantistas (Jerusalén: Universidad Hebrea de Jerusalén), pp. 55-78

Fernández Clemente, Eloy; Marco Simón, Francisco. 2008. Historia de Aragón (Zaragoza: La Esfera de los Libros)

Fernández Martín, Luis. 1980. 'El hogar donde Iñigo de Loyola se hizo hombre: I506-I5I7', Archivum Historicum Societatis Iesu, 49: 2I-94

Fernández Martín, Luis. I993. 'Nuevas aportaciones históricas acerca de la juventud y la familia de San Ignacio de Loyola', in Ignacio de Loyola en la gran crisis del siglo xvi: Congreso Internacional de Historia, Madrid, 1991, ed. by Quintín Aldea (Bilbao: Ediciones Mensajero), pp. II9-42

Fernández de Oviedo, Gonzalo. 1983-2002. Batallas y quinquagenas, ed. by Juan Pérez de Tudela y Bueso (Madrid: RAH), 4 vols

Fernández de Velasco, Pedro, Duke of Frías. Origen de la Yllustrísima Casa de Velasco por Don Pedro Fernández de Velasco, condestable de Castilla, duque de Frías [d. I559]. Bibl. Nac. de España, Ms3238 [c. I55o] 〈https://go.uv.es/Lqicn6E $>$

Fita, Fidel. I89o. 'San Ignacio de Loyola en la corte de los Reyes de Castilla. Estudio crítico', BRAH, I7: 492-520 <https://go.uv.es/Qt2CDMq $>$

Fitzmaurice-Kelly, James. I9I3. Miguel de Cervantes Saavedra, a Memoir (Oxford: Clarendon Press)

Forcione, Alban K. 1982. Cervantes and the Humanist Vision: A Study of Four Exemplary Novels (Princeton, NJ: Princeton University Press) 
Galíndez de Carvajal, Lorenzo. I851. 'Adiciones genealógicas a los Claros varones de Castilla, de Fernán Pérez de Guzmán, Señor de Batres [I5I7]’, CODOIN, ed. by Miguel Salvá and Pedro Sáinz de Baranda, vol. I8 (Madrid: RAH)

Galíndez de Carvajal, Lorenzo. 1878. Anales breves del reinado de los Reyes Católicos D. Fernando y Doña Isabel, ed. by Cayetano Rosell, in Crónicas de los reyes de Castilla, BAE, $7 \mathrm{O}$ (Madrid: Rivadeneyra), iii: $533-65$

Garcés, María Antonia. 1995. 'Delirio y obscenidad en Cervantes: el caso Vidriera', Actas de la Asociación Internacional de Hispanistas (Birmingham: University of Birmingham), xii: 225-36

García Lorca, Francisco. I965.'El Licenciado Vidriera y sus nombres', Revista Hispánica Moderna, 3I: I59-I68 <https://go.uv.es/8EcwmIH>

Gómez Canseco, Luis. 20I5. 'Los membrillos de Cervantes', Monteagudo, 20: 4I-53 $<\underline{\text { https:// }}$ go.uv.es/ $\mathrm{uP}_{5} \mathrm{YCPO}>$

Green, Otis H., I97o. 'El Licenciado Vidriera: Its Relation to the Viaje del Parnaso and the Examen de Ingenios of Huarte', in his The Literary Mind of Medieval and Renaissance Spain (Lexington: The University of Kentucky) <https://uknowledge.uky.edu/upk_spanish_literature/I4/>

Gutiérrez, Jesús. 1992. 'El Celoso, entre La Celestina y el Decamerone', in Actas del X Congreso de la Asociación Internacional de Hispanistas, Barcelona 1989, vol. I (Barcelona: Promociones y Publicaciones Universitarias), i: $233-40$

Hemery, Gabriel; Sarah Simblet. 20I4. The New Sylva: A Discourse of Forest and Orchard Trees for the Twenty-First Century (London: A \& C Black)

Huarte de San Juan, Juan. I989. Examen de ingenios para las ciencias, ed. by Guillermo Serés (Madrid: Cátedra)

Ingram, Kevin. 2006. Secret Lives, Public Lies: The Conversos and Socio-Religious Non-Conformism in the Spanish Golden Age, $\mathrm{PhD}$ thesis (San Diego, University of California) $<\underline{\text { https:// }}$ escholarship.org/uc/item/6270j25z>

Iriarte, Mauricio de. 1933. 'El Ingenioso Hidalgo y El Examen de ingenios: qué debe Cervantes al Dr. Huarte de San Juan', in Revista Internacional de Estudios Vascos, 24: 499-522 < $\underline{\text { https:/ / www. }}$ filosofia.org/hem/193/acc/e42535.htm>

Johnson, Carroll B. 1983. Madness and Lust: A Psychoanalytical Approach to Don Quixote (Berkeley: University of California Press)

Jones, Richard. 20I3. The Medieval Natural World (London: Routledge)

Ladero Quesada, Miguel Ángel. r993. 'Ecos de una educación caballeresca', in Ignacio de Loyola en la gran crisis del siglo xvi (Congreso Internacional de Historia, Madrid, I9-2I noviembre de I99I), ed. by Quintín Aldea (Bilbao: Ediciones Mensajero), pp. I43-50

Laguna, Andrés de (trans.). I999. Pedacio Dioscórides Anazarbeo Acerca de la materia medicinaly de los venenos mortíferos (Madrid: Fundación de Ciencias de la Salud) [Salamanca: Mathias Gast I566]

López, Diego. I6I5. Declaración magistral sobre las Emblemas de Andrés Alciato (Nájera: Juan de Mongastón) $<\underline{\text { https: / go.uv.es/FIKLFJo }}>$

López de Haro, Alonso. I622. Nobiliario genealógico de los reyes y títulos de España (Madrid: Luis Sánchez), 2 vols $<\underline{\text { https://go.uv.es/LY8Cxyc }>}$ 
Loyola, Ignacio de. I963. Autobiografia, in Obras completas, ed. by Ignacio Iparraguirre and

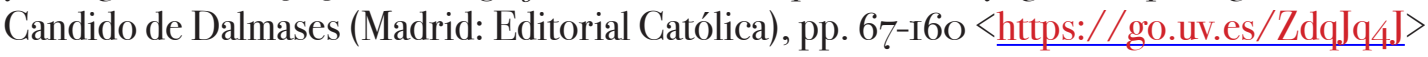

Lynn, Caro. 1937. A College Professor of the Renaissance: Lucio Marineo Sículo among the Spanish Humanists (Chicago: University of Chicago Press)

Molho, Maurice. I995. 'Una dama de todo rumbo y manejo: para una lectura de El licenciado Vidriera', in Erotismo en las letras hispánicas: aspectos, modos y fronteras, ed. by Luce López Baralt and Francisco Márquez Villanueva (Mexico City: Colegio de México), pp. 387-406

Núñez, Hernán. 2OOI. Refranes o proverbios en romance, ed. by Louis Combet, Julia Sevilla Muñoz, Germán Conde Tarrió and Josep Guia i Marín (Madrid: Guillermo Blázquez), 2 vols [Salamanca I555]

Ortés, Federico. 2002. El triunfo de Don Quïote: Cervantes y la Compañía de Jesús, un mensaje cifrado (Seville: Muñoz Moya)

Parker, Patricia. 2003. '(Peter) Quince: Love Potions, Carpenters, Coigns and Athenian Weddings', in Shakespeare Survey: An Annual Survey of Shakespeare Studies and Production, 56: 39-54

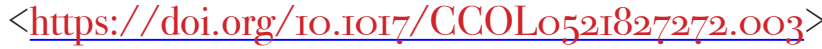

Perea Rodríguez, Óscar. 20I4. 'Hacia un censo comentado de ejemplares del Cancionero general de Hernando del Castillo: la primera edición valenciana (I5II)', in 'Vir bonus dicendi peritus': Studies in Honour of Charles B. Faulhaber, ed. by Antonio Cortijo Ocaña, Ana M. Gómez-Bravo and María Morrás (New York: Hispanic Seminary of Medieval Studies), pp. 153-207

Platina, Bartholomaeus. 1998. On Right Pleasure and Good Health: A Critical Edition and Translation of De Honesta Voluptate et Valetudine, ed. by Mary Ella Milham (Tempe, Az: Medieval and Renaissance Texts \& Studies)

Porras Arboledas, Pedro A. 1997. La orden de Santiago en el siglo xv (Madrid: Dykinson) <https:// go.uv.es/3pBynqW>

Price, R. M. (trans.). 1992. Miguel de Cervantes Saavedra Exemplary Novels, vol. 2 (Warminster: Aris \& Philips)

Redondo, Augustin. 198I. 'La Folie du cervantin Licencié de Verre: traditions, contexte historique et subversion', in Visages de la folie (1511-1650) (domaine hispano-italien), ed. by Augustin Redondo and André Rochon (Paris: Publications de la Sorbonne I6), pp. 33-44. [2 $2^{\text {nd }}$ edn in Redondo's Revisitando las culturas del Siglo de Oro. Mentalidades, tradiciones culturales, creaciones paraliterarias y literarias (Salamanca: Universidad de Salamanca, 2007)]

Redondo, Augustin, 20II. En busca del Quijote desde la otra orilla (Alcalá de Henares: Centro de Estudios Cervantinos)

Sánchez, Alberto. 1997. 'Revisión del cautiverio cervantino en Argel', Cervantes: Bulletin of the Cervantes Society of America, I7: 7-24 <https://go.uv.es/KrAYIAn>

Sampayo Rodríguez, José Ramón. 1986. Rasgos erasmistas de la locura del Licenciado Vidriera de Miguel de Cervantes (Kassel: Edition Reichenberger)

Sandoval, Fray Prudencio de. 1955-56. Historia de la vida y hechos del Emperador Carlos V, ed. by Carlos Seco Serrano, BAE, 80-82 (Madrid: Ediciones Atlas), 3 vols

Sandoval, Fray Prudencio de. I625. Historia dela vida y hechos del Emperador Carlos V(Barcelona: Sebastian de Cormellas) 〈https://digibug.ugr.es/handle/IO48I/II934> 
Santa Cruz, Alfonso de. 2005. Sobre la melancolía: diagnóstico y curación de los afectos melancólicos, ed. by Juan Antonio Paniagua (Pamplona: Ediciones Universiadad de Navarra) [Diagnotio et cura affectuum melancholicorum (Madrid: apud Thomam Iuntam, I622)]

Santa Cruz, Alonso de. I951. Crónica de los Reyes Católicos, ed. by Juan de Mata Carriazo (Seville: Escuela de Estudios Hispano-Americanos)

Schleiner, Winfried. 1991. 'The Glass Graduate and the Aphrodisiac that Went Wrong: New Light from Old Texts', Forum for Modern Language Studies, 27: 37O-8I < https://doi.org/Io.Iog3/ $\underline{\mathrm{fmls} / \mathrm{XXVII} \cdot 4 \cdot 370>}$

Shipley, George. 200I. 'Garbage In, Garbage Out: "The Best of Vidriera", Cervantes: Bulletin of the Cervantes Society of America, 2I: 5-4I <https://go.uv.es/EZgutg2 >

Shipley, George. 2002. 'Vidriera's Blather', Cervantes: Bulletin of the Cervantes Society of America, 22: 49 -I24 <https://go.uv.es/JFIvB2Z>

Shipley, George. 2005. 'Cervantes' Licenciado Vidriera Was No Ordinary Fool', Bulletin of Hispanic Studies, 82: 718-3I <https://doi.org/IO.3828/bhs.82.5.II $>$

Soufas, Teresa Scott. 1990. Melancholy and the Secular Mind in Spanish Golden Age Literature (Columbia: University of Missouri Press)

Speak, Gill. 1990. 'El licenciado Vidriera and the Glass Men of Early Modern Europe', The Modern Language Review, 85 : 850-65 < $\underline{\text { http://doi.org/IO.2307/3732644> }}$

Varo, Carlos (ed.). r981. Carajïcomedia: texto facsimilar (Madrid: Playor)

Velázquez de Velasco, Alfonso. I602. La Lena, o Elceloso (Milan: Herederos de Pacifico Poncio et Ian Bautista Picalia)

Wehr, Christian. 20II. 'Imaginación - identificación - imitación: Don Quijote, Ignacio de Loyola y la espiritualidad jesuítica', in Ortodoxia, y heterodoxia en Cervantes, ed. by Carmen Rivero Iglesias (Alcalá de Henares: Centro de Estudios Cervantinos), pp. I59-72

Wilson, C. Anne. I991. 'Banqueting Stuffe': The Fame and Social Background of the Tudor and Stuart Banquet (Edinburgh: Edinburgh University Press)

Wilson, C. Anne. 200o. The Book of Marmalade, 2nd edn (Philadelphia: University of Pennsylvania Press)

Zúñiga, Francés de. 1981. Crónica burlesca del Emperador Carlos V, ed. by Diane Pamp de AvalleArce (Barcelona: Crítica) 